\title{
Melanoma in pregnancy - where we are?
}

\section{Czerniak w ciq̨ży - aktualny stan wiedzy}

\section{Dariusz Izycki ${ }^{1}$, Christopher Patrick Kerrigan², Maciej Kazmierczak³}

${ }^{1}$ Department of Cancer Immunology, Poznan University of Medical Sciences;

Head of Department: Prof. Andrzej Mackiewicz

2Poznan University of Medical Sciences;

${ }^{3}$ Department of Hematology, Poznan University of Medical Sciences;

Head of Department: Prof. Mieczysław Komarnicki

Przegląd Menopauzalny 2013; 6: 493-495

\section{Summary}

With rising rates of melanoma and women bearing children at older ages, the incidence of malignant melanoma in pregnancy will continue to increase. Initial reports in the 1950s portrayed a belief of the medical community that pregnant women who were diagnosed with malignant melanoma suffered a poorer prognosis. Numerous studies since then have shown that this is not the case, and pregnancy has not been shown to have a negative impact on the prognosis of malignant melanoma. Various mechanisms of hormones affecting malignant melanoma have been proposed, although nothing conclusive has been found. And although very rare, fetal metastasis is a serious risk and needs to be kept under consideration. Continual research and period reviews are necessary to best understand any effects of pregnancy on malignant melanoma, guide research, and maximize patient care.

Key words: melanoma malignum, pregnancy.

\section{Streszczenie}

Czerniak złośliwy stanowi $25 \%$ wszystkich nowotworów diagnozowanych w czasie ciąży. Wstępne doniesienia z początku lat 50. poprzedniego stulecia postulowały gorsze rokowanie w zakresie całkowitych przeżyć oraz okresu wolnego od choroby w przypadku kobiet w ciąży ze zdiagnozowanym czerniakiem. Sugerowano istnienie mechanizmu wieloczynnikowej immunosupresji promującej progresję nowotworu oraz wpływ hormonów płciowych na wzrost proliferacyjnej aktywności komórek czerniaka. Jednak kolejne dane literaturowe wykluczyły możliwość istnienia negatywnej korelacji pomiędzy ciążą a dynamiką rozwoju i stopniem zaawansowania klinicznego czerniaka. Sprzeczne doniesienia naukowe, a także rozbieżne wnioski dotyczące ryzyka przerzutów czerniaka złośliwego do płodu narzucają konieczność kontynuowania badań klinicznych w celu lepszego zrozumienia wpływu ciąży na rozwój czerniaka.

Słowa kluczowe: czerniak złośliwy, ciąża.

\section{Introduction}

Malignant melanoma $(\mathrm{MM})$ is responsible for up to $25 \%$ of all malignancies diagnosed during pregnancy [1]. Estimated incidence of melanoma complications during pregnancy ranges from 0.1 to 2.8 per 1,000 pregnancies $[2,3]$. A study based on the incidence and survival of MM in Scotland in 1979-1998 showed an incidence change from 7 to 13.1 per 100,000, an increase of $187 \%$ [4]. With rising rates of melanoma and increasing maternal age, the impact of MM on pregnancy will only increase.
The controversy over the role of pregnancy on MM began with early case reports that suggested that pregnancy may induce the transformation of melanocytic nevi into MM or accelerate metastasis. In addition, the observation of physiological hyperpigmentation of multiple cutaneous sites during pregnancy supported the theory that pregnancy-related hormones may play a crucial role in the development of MM in women [2]. Another theory supporting the potential influence of pregnancy on MM development is relating to the immunosuppression state 
which can promote MM initiation and progression. Possible mechanisms may include activation of Th2 - helper lymphocyte, expression of $\mathrm{B} 7-\mathrm{H} 1$ ligand on the trophoblast cells, which induces activated T cells subpopulation and inhibition of natural killer cell-mediated cytotoxicity by overexpression of HLA-G on melanoma cells. In order to pursue new treatment guidelines and better inform patients, a periodic review of current studies is necessary to best understand the effects of pregnancy on MM.

\section{Role of hormones}

With the developed understanding of the importance of sex hormone receptors in cancers such as breast and prostate cancers on treatment and prognosis, it is important to consider whether MM can also be significantly affected by changes in sex hormones, particularly when considering the diagnosis in pregnancy. Studies have shown the presence of estrogen receptors in $M M$ cells using biochemical and histochemical tests, however, their presence has not been shown in immunohistochemical tests utilizing monoclonal antibodies [5].

Despite uncertain conclusions of the role of estrogen receptors, attempts have been made to utilize Tamoxifen in $M M$ treatment due to its role in other estrogen receptor positive malignancies. A study of Tamoxifen as a single agent for advanced melanoma in post-menopausal women showed a response rate of only $7 \%$ [6].

When considering the possible role of hormone changes on clinical outcome of MM, studies of the effects of oral contraceptives on $M M$ provide valuable information. Since the invention of the oral contraception, scientists have extensively studied the impact of its use on MM. A study on Californian women taking oral contraceptives in the 1970s showed an increased risk of melanoma, but the sample sizes were too small to draw any conclusions [4]. In the 1980s, a study showed a slightly increased risk of MM in women taking oral contraceptives for more than 5 years, but the findings were not statistically significant [5]. In the 1990s, longer-term studies and serial case-control study reviews showed no effect of the oral contraception on the incidence of MM [7]. In 2002, a pooled analysis of 10 case-controlled studies showed no correlation between the use of oral contraceptives and cutaneous MM [8]. Despite some initial uncertainty, studies over the past four decades have shown no risk of oral contraceptives in MM.

\section{Prognosis for women with malignant melanoma during pregnancy}

One method for speculating on the effect of pregnancy on $M M$ is to examine any histological changes. A study of tumor thickness in a Swedish population found a thickness of $1.28 \mathrm{~mm}$ in pregnant women and
$1.07 \mathrm{~mm}$ in non-pregnant women, the findings were not statistically significant [9]. A WHO study found a statistically increased tumor thickness in pregnant women versus non-pregnant controls, despite finding no impact of pregnancy on MM outcome [10]. Furthermore, a large population-based study found no significant difference in MM tumor thickness in pregnancy [11] and melanoma in pregnancy survival study showed the same [12]. Overall, there is little evidence to support that physiologic changes of pregnancy significantly affect the histopathology of MM.

Large-scale studies involving thousands of women have shown no significant correlation between localized melanoma diagnosis made during pregnancy and survival $[11,12]$. Some studies have shown a shortened disease-free interval in patients diagnosed in pregnancy, while other larger studies have shown no correlation. The disease-free interval in pregnancy is still controversial and needs further studies. It has been postulated that factors such as physiological immunosuppression or less aggressive treatments in pregnant women may account for a possible shortened disease-free interval in pregnancy [13]. An increase in growth factors related to pregnancy has also been postulated as a possible mechanism for possible influence of growth on MM cells [14].

\section{Treatment options}

The evidence to date has failed to show any major influence of pregnancy on the progression of MM. The European Society for Medical Oncology currently recommends the same treatment standards for a patient diagnosed with $M M$, regardless of the pregnancy status [15]. Preventive measures including frequent dermatological examinations and prompt biopsy of any suspicious lesion, particularly for high-risk women, remains the most important method of treatment for women in pregnancy. There is limited experience in treating pregnant women with advanced metastatic MM requiring chemotherapy and interferon. However due to limited reports, chemotherapy regimen or immunotherapy with interferon should only be used in exceptional cases of widespread metastasis because of potential severe side effects $[16,17]$.

A recent French national retrospective study of 22 women with stage III/IV melanoma diagnosed during pregnancy who received conventional MM treatment (except during the first trimester) showed no serious side effects, except for one case of miscarriage after surgery. All patients with an American Joint Committee on Cancer stage III/IV diagnosis were included. Mortality rates did not suggest a worsened prognosis due to pregnancy, although due to the small sample size, further study is needed [18]. 


\section{Fetal risk}

Metastasis to the fetus via the placenta is extremely rare. However, a 2003 study found MM to be the most common cause, accounting for $31 \%$ of the total cases found. With placental involvement there is an approximately $22 \%$ risk of melanoma to the fetus. It should be noted that the total number of cases of placental or fetal metastasis found for this study dating back to 1866 was 87, 27 of which were MM [19]. Despite its rarity, pregnant women with MM should be examined by pathologists to monitor for placental involvement.

\section{Discussion and future research}

The role of pregnancy and hormones on $M M$ is not yet fully understood. Utilization of any possible hormone receptors may yield valuable information as it has for other cancers, but the existing data are still inconclusive. Birth control and pregnancy have not been shown to increase the risk or severity of MM. Doctors should be mindful of high-risk patients, and prevention and early diagnosis should be of the highest priority. Current data support that pregnancy should not prevent the treatment of patients with $M M$, and pregnancy termination is not necessary. And although rare, fetal metastasis should always be considered, and the placenta should be pathologically monitored.

Although there are sufficient data to support the claim that pregnancy does not affect the prognosis in $\mathrm{MM}$ patients, further research is needed to better understand what influence pregnancy has on MM. Any confirmed changes in the histopathology of $\mathrm{MM}$, or in the diseasefree interval during pregnancy would provide valuable information on the disease and provide clues for future treatment endeavors. With an increasing incidence of MM and pregnancy rates increasing in older women, understanding of the situation will only become of greater importance. Informed primary care providers will be the key in prevention and early detection. Furthermore, a continual review of cases involving placental/fetal malignancies is imperative to fully appreciate any risk to the fetus.

\section{References}

1. Lens $M$, Bataille V. Melanoma in relation to reproductive and hormonal factors in women: current review on controversial issues. Cancer Causes Control 2008; 19: 437-42.

2. Villani GM, Goldberg GL. Nongenital malignancies. In: Cherry and Merkatz's Complications of Pregnancy. Cohen W (ed). Lippincott Williams and Wilkins, Philadelphia 2000; 624-7.

3. O’Reilly S, Chakravarthy A. Other cancers in pregnancy. In: Cancer Obstetrics and Gynecology. Trimble E, Trimble C (eds.). Lippincott Williams and Wilkins, Philadelphia 1999; 249-59.

4. Miller JG, Neil SM. Gender and cutaneous melanoma. Br J Dermatol 1997; 136: 657-65.

5. Rumke P, Kleeberg UR, Mackie RM, et al. Tamoxifen as a single agent for advanced melanoma in postmenopausal women. A phase II study of the EORTC malignant melanoma cooperative group. Melanoma Res 1992; 2: 153-6.

6. Jhaveri M, Driscoll M, Grant-Kels J. Melanoma in pregnancy. Clin Obstet Gynecol 2011; 54: 537-45.

7. Pfahlberg A, Hassan K, Wille L, et al. Systematic review of case-control studies: oral contraceptives show no effect on melanoma risk. Public Health Rev 1997; 25: 309-15.

8. Mackie RM, Bray CA, Hole DJ, et al. Incidence of and survival from malignant melanoma in Scotland: an epidemiological study. Lancet 2002; 360: 587-91.

9. Lens MB, Rosdahl I, Ahlbom A, et al. Effect of pregnancy on survival in womenwith cutaneous malignant melanomas. J Clin Oncol 2004; 22: 4369-75.

10. O'Meara AT, Cress R, Xing G, et al. Malignant melanoma in pregnancy. A population-based evaluation. Cancer 2005; 103: 1217-26.

11. Lens MB, Rosdahl I, Ahlbom A, et al.Effect of pregnancy on survival in women with cutaneous malignant melanomas. J Clin Oncol 2004; 22: 4369-75.

12. Karagas MR, Stukel TA, Dykes J, et al.A pooled analysis of 10 case-control studies of melanoma and oral contraceptive use. Br J Cancer 2002; 86: 1085-92.

13. Mackie RM. Pregnancy and exogenous hormones in patients with cutaneous malignant melanoma. Curr Opin Oncol 1999; 11: 129-31

14. Pentheroudakis G, Orecchia R, Hoekstra HJ, et al. Cancer, fertility and pregnancy: ESMO Clinical Practice Guidelines for diagnosis, treatment and followup. Ann Oncol 2010; 21 (suppl 5): v266-73.

15. Pagès $C$, Robert $C$, Thomas $L$, et al. Management and outcome of metastatic melanoma during pregnancy. Br J Dermatol 2010; 162: 274-81.

16. Mackiewicz J, Mackiewicz A. Recent advances in melanoma treatmentAmerican Society of Clinical Oncology (ASCO) 2012 perspective. Wspolczesna Onkol 2012; 16: 197-200.

17. Cybulska-Stopa B, Skoczek M, Ziobro M, et al. Results of systemic treatment of cutaneous melanoma in inoperable stage III and IV. Wspolczesna Onkol 2012; 16: 532-45

18. Alexander A, Samlowski WE, Grossman D, et al. Metastatic melanoma in pregnancy: risk of transplacental metastases in the infant. J Clin Oncol 2003; 21: 2179-86.

19. Beral V, Ramcharan S, Faris R. Malignant melanoma and oral contraceptive use among women in California. Br J Cancer 1977; 36: 804-9.

20. Adam SA, Sheaves JK, Wright NH, et al. A case-control study of the possible association between oral contraceptives and malignant melanoma. Br J Cancer 1981; 44: 45-50.

21. MacKie RM, Bufalino R, Morabito A, et al. Lack of effect of pregnancy on outcome of melanoma. For the World Health Organisation Melanoma Programme. Lancet 1991; 337: 653-5. 